\title{
Internalisasi Nilai-Nilai Fikih dalam Kitab Fath Al-Qorib
}

\author{
Sholeh Hasan \\ STKIP Nurul Huda OKU Timur \\ E-mail: sholehhasan@stkipnurulhuda.ac.id
}

INFO ARTIKEL

\section{Available online}

URL:

https://journal.stkipnurulhuda.ac.id/ index.php/JIMi/article/view/447

How to cite (APA):

Hasan, S. (2019). Internalisasi Nilai-Nilai Fikih dalam Kitab Fath Al-Qorib. Jurnal Indonesia Mengabdi, 1(1), 16-20.

This work is licensed under a Creative Commons Attribution 4.0 International License

\section{ABSTRAK}

\begin{abstract}
Abstrak
Internalisasi nilai dalam membentuk sebuah karakter yang diinginkan tentu memerlukan proses yang terencana dengan baik. Bisa melalui hubungan individual, kelompok maupun kelembagaan. Pesantren Darul Ihya sebagai lembaga pendidikan nonformal diharapkan memberikan peran dalam membentuk manusia yang berkarakter islami. Di pesantren ini penulis jadikan media pengabdian dalam rangka internalisasi nilai-nilai fikih dalam kitab Fath Al-Qorib. Dengan menggunakan metode bandongan, sekelompok murid dalam satu kelas mendengarkan seorang ustadz yang membaca, menerjemahkan, menerangkan materi yang ada di dalam kitab Fath al-Qorib. Setiap santri memperhatikan kitabnya dan membuat catatan tentang kata-kata atau buah pikiran yang sulit, berupa syakl atau makna mufrodat. Pembelajaran kitab kuning yang selama ini dilaksanakan di pesantren Darul Ihya, memiliki implikasi yang cukup besar terhadap pembentukan karakter islami bagi para santri. Sehingga hadirnya penulis selain dapat memenuhi kekurangan sumberdaya manusia yang dialami pondok pesantren Darul Ihya juga dapat memberikan kontribusi dalam menjalankan program yang dicanangkan oleh pesantren.
\end{abstract}

Kata kunci: Internalisasi, Fikih, Fath al-Qorib

\section{PENDAHULUAN}

Satu di antara puluhan lembaga pendidikan yang mempunyai kekhasan tersendiri dan berbeda dengan 
lembaga pendidikan yang lainnya adalah pesantren. Di tinjau dari segi historisnya, pesantren merupakan bentuk lembaga pribumi tertua di Indonesia. Pesantren sudah dikenal jauh sebelum Indonesia merdeka, bahkan sejak Islam masuk ke Indonesia, pesantren terus berkembang sesuai dengan perkembangan dunia pendidikan pada umumnya. Ada dua pendapat mengenai awal berdirinya pondok pesantren di Indonesia. Pendapat pertama menyebutkan bahwa pondok pesantren berakar pada tradisi Islam sendiri dan pendapat kedua menyatakan bahwa sistem pendidikan model pondok pesantren adalah asli Indonesia (DEPAG RI: 2003).

Pondok pesantren Darul Ihya sebagai komunitas dan sebagai lembaga pendidikan yang jumlah santrinya semakin tahun semakin berkembang telah banyak memberikan peran dalam membentuk manusia yang religious. Namun semenjak meninggalnya Kiai Muhyidin sebagai pendiri dan perintis lembaga Pondok Pesantren Darul Ihya mengalami krisis tenaga pendidik dan bahkan ada kemerosotan jumlah santri. Di kalangan masyarakat sekitar sendiri sosok Kiai Muhyidin memang dipandang sebagai sosok yang karismatik dan memiliki daya asuh yang cukup baik. Beliau wafat di usia yang masih muda, itulah yang kemudian menjadikan masyarakat cukup merasa kehilangan.

Kini pondok pensantren Darul Ihya sudah mulai bangkit untuk mengembangkan lembaga pendidikan diniyah. Kendala yang masih dihadapi saat ini adalah kurangnya tenaga pendidik di madrasah diniyah. Untuk itu penulis dengan berbekal niat dan kemampuan keilmuan yang ada memantabkan diri untuk mengabdi demi keberlanjutan lembaga pendidikan madrasah diniyah di Pondok Pesantren Darul Ihya.

\section{SOLUSI METODE}

Dengan menggunakan metode bandongan atau istilah lain wetonan penulis melakukan pembelajaran di dalam kelas. Secara etimologi, dalam kamus besar Bahasa Indonesia, bandongan diartikan dengan pengajaran dalam bentuk kelas (pada sekolah agama). Dalam sistem ini sekelompok murid (antara 5 sampai 500) mendengarkan seorang guru yang membaca, menerjemahkan, menerangkan dan seringkali mengulas buku-buku Islam dalam Bahasa Arab. Setiap santri memperhatikan kitabnya dan membuat catatan tentang kata-kata atau buah pikiran yang sulit, berupa syakl atau makna mufrodat. Kelompok kelas dari sistem bandongan ini disebut dengan halaqoh yang arti bahasanya lingkaran murid atau sekelompok siswa yang belajar di bawah bimbingan seorang ustadz.

Atas berbagai kekurangan dan kelebihan yang dimiliki pondok pesantren Darul Ihya sangat diperlukan kontribusi para alumni pondok pesantren salaf untuk turut serta melestarikan pendidikan pesantren yang kian hari semakin besar tantangan dalam menghadapi arus modernisasi. Sehingga perlu muncul kesadaran di kalangan alumni pesantren dan pegiat pendidikan dalam mengambil langkah-langkah pembaharuan untuk menjawab tantangan dan kebutuhan dalam rangka internalisasi nilai-nilai keagamaan yang banyak termaktub dalam kitab fikih klasik. Hal ini senada dengan apa yang disampaiak Azyumardi (2001:51) "Pesantren harus menumbuhkan apresiasi yang sepatutnya terhadap semua perkembangan yang terjadi di masa kini dan mendatang, sehingga dapat memproduksi ulama yang berwawasan luas." Itulah kenapa pesantren harus tetap berdiri kokoh meski jaman terus berjalan di tengah arus modernisasi.

\section{HASIL DAN DISKUSI}

Lembaga-lembaga pendidikan yang ada saat ini banyak, baik itu yang berada dijalur pendidikan formal, nonformal dan informal. Proses pengembangan pembelajaran kitab kuning yang selama ini telah dilaksanakan melalui jalur pendidikan nonformal seperti di pesantren Darul Ihya, memiliki implikasi yang cukup besar terhadap pembentukan karakter islami bagi para santri. Sehingga hadirnya penulis selain dapat memenuhi kekurangan sumberdaya manusia yang dialami pondok pesantren Darul Ihya juga dapat memberikan kontribusi dalam menjalankan program yang dicanangkan oleh pesantren.

Adanya kendala-kendala yang dihadapi oleh pesantren Darul Ihya dalam mengembangkan pembelajaran kitab kuning, bukan berarti pelaksanaan pengembangan pembelajaran kitab kuning tidak dapat dilaksanakan, hanya saja untuk melaksanakan program pengembangan pembelajaran kitab kuning tersebut 
harus didukung oleh para asatidz yang mempunyai kapasitas keilmuan memadai. Sehingga pesan-pesan yang tersurat dalam kitab dapat tersampaikan dengan baik dan terarah.

\section{PEMBAHASAN}

Perjalana pondok pesantren Darul Ihya dalam mengawal program serta visi-misi yang diemban memang cukup memberikan tantangan. Sampai saat ini pendidikan di Pondok pesantren Darul Ihya berjalan dengan memanfaatkan gedung madrasah yang masih minim fasilitas. Gedung yang masih berlantaikan semen kasar serta atap yang belum diplafon menjadikan suasana ruangan terkesan kotor.

Di masjid dan serambi masjid dimanfaatkan sebagai ruang untuk belajar akibat kurangnya lokasi madrasah. Maka akan sedikit bising jika terdapat dua kelas yang sama-sama menggunakan serambi masjid. Kondisi ini yang menjadikan tantangan bagi para ustadz untuk dapat mengatur dan mengkondisikan supaya proses pembelajaran berjalan dengan kondusif.

Di sisi lain, lokasi pondok pesantren Darul lhya yang persis berada di pinggir sawah ini cukup strategis dan tenang untuk melakukan aktifitas pondok pesantren sehingga tidak tercampur dengan hiruk pikuknya dunia luar. Dan Di pondok ini para santri melakukan segala aktifitasnya, baik belajar, diskusi, makan, mandi, mencuci, berlatih kegiatan islami hingga tidur dan beristirahat dengan tenang.

Dalam pelaksanaan pengabdian ini penulis laporkan bahwa pelaksanaan kegiatan efektif yang dapat dilakukan hanya sampai dengan akhir Mei dengan jumlah 22 kali tatap muka. Hal ini karena disesuaikan dengan program dari pondok pesantren ketika menjelang awal bulan Ramadhan yang pada saat program pengabdian ini berjalan bertepatan pada bulan Juni seluruh kegiatan pembelajaran yang dilakukan di madrasah diniyah harus diselesaikan. Karena pada saat bulan Ramadhan program pondok pesantren sudah berganti dengan pengajian kilatan, yaitu program pengajian kitab harus selasai (khatam) dalam jangka waktu selama bulan Ramadhan. Sehingga 26 kali tatap muka yang sudah penulis agendakan harus berhenti pada pertemuan ke 22. Rangkaian kegiatan pertemuan tersebut penulis paparkan dalam sebuah tabel:

Tabel 1. Rangkaian Kegiatan

\begin{tabular}{|l|c|c|c|c|c|}
\hline \multirow{2}{*}{ Jenis Kegiatan } & \multicolumn{5}{|c|}{ Bulan Ke.. } \\
\cline { 2 - 6 } & $\mathbf{1}$ & $\mathbf{2}$ & $\mathbf{3}$ & $\mathbf{4}$ & $\mathbf{5}$ \\
\hline Minggu ke 1 & Pertemuan & Pertemuan & Pertemuan & Pertemuan & Pertemuan \\
& 1 & 6 & 10 & 14 & 18 \\
\hline Minggu ke 2 & Pertemuan & Pertemuan & Pertemuan & Pertemuan & Pertemuan \\
& 2 & 7 & 11 & 15 & 19 \\
\hline Minggu ke 3 & Pertemuan & Pertemuan & Pertemuan & Pertemuan & Pertemuan \\
& 3 & 8 & 12 & 16 & 20 \\
\hline Minggu ke 4 & Pertemuan & Pertemuan & Pertemuan & Pertemuan & Pertemuan \\
& 4 & 9 & 13 & 17 & 21 \\
\hline Minggu ke 5 & Pertemuan & - & - & - & Pertemuan \\
& 5 & & & & 22 \\
\hline
\end{tabular}

Namun demikian menurut hemat penulis hal ini sudah cukup memberikan wawasan yang efektif dan bekal bagi satriwan dan santriwati untuk memperdalam kajian kitab fath al-Qorib. Pertemuan ini diakhiri dengan materi syarat wajib dan shalat sunnah dan dilanjut dengan penutupan pengabdian.

Dalam kegiatan pengabdian kepada masyarakat ini materi yang penulis sampaikan dalam setiap pertemuan dapat dilihat pada tabel di bawah ini:

\section{Tabel 2. Realisasi Program}

\begin{tabular}{|l|l|l|l|l|}
\hline No & Tanggal & \multicolumn{1}{c|}{ Waktu } & \multicolumn{1}{c|}{ Materi } & \multicolumn{1}{c|}{ Penyaji } \\
\hline 1 & 03 Jan. 2018 & $18.45-20.15$ & BAB Toharoh (Bersuci) & Sholeh Hasan, M.Pd.I \\
\hline 2 & 10 Jan. 2018 & $18.45-20.15$ & Kulit yang Disamak & Sholeh Hasan, M.Pd.I \\
\hline 3 & 17 Jan. 2018 & $18.45-20.15$ & Hukum Siwak & Sholeh Hasan, M.Pd.I \\
\hline 4 & 24 Jan. 2018 & $18.45-20.15$ & Fardhu Wudhu Ada 6 & Sholeh Hasan, M.Pd.I \\
\hline 5 & 31 Jan. 2018 & $18.45-20.15$ & Sunnah Wudhu Ada 10 & Sholeh Hasan, M.Pd.I \\
\hline
\end{tabular}




\begin{tabular}{|l|l|l|l|l|}
\hline No & Tanggal & \multicolumn{1}{|c|}{ Waktu } & \multicolumn{1}{c|}{ Materi } & \multicolumn{1}{c|}{ Penyaji } \\
\hline 6 & 07 Feb. 2018 & $18.45-20.15$ & Hukum Istinjak & Sholeh Hasan, M.Pd.I \\
\hline 7 & 14 Feb. 2018 & $18.45-20.15$ & $\begin{array}{l}\text { Yang Sunnah Saat Kencing dan } \\
\text { BAB }\end{array}$ & Sholeh Hasan, M.Pd.I \\
\hline 8 & 21 Feb. 2018 & $18.45-20.15$ & Yang Membatalkan Wudhu & Sholeh Hasan, M.Pd.I \\
\hline 9 & 28 Feb. 2018 & $18.45-20.15$ & Yang Mewajibkan Mandi Besar & Sholeh Hasan, M.Pd.I \\
\hline 10 & 07 Mar. 2018 & $18.45-20.15$ & Wajib dan Sunnahnya Mandi & Sholeh Hasan, M.Pd.I \\
\hline 11 & 14 Mar. 2018 & $18.45-20.15$ & Keadaan yang Disunnahkan Mandi & Sholeh Hasan, M.Pd.I \\
\hline 12 & 21 Mar. 2018 & $18.45-20.15$ & Mengusap Khuf (Kaus Kaki) & Sholeh Hasan, M.Pd.I \\
\hline 13 & 28 Mar. 2018 & $18.45-20.15$ & Tayamum: Syarat, Rukun, Sunnah & Sholeh Hasan, M.Pd.I \\
\hline 14 & 04 Apr. 2018 & $18.45-20.15$ & Pembatal Tayamum & Sholeh Hasan, M.Pd.I \\
\hline 15 & 11 Apr. 2018 & $18.45-20.15$ & Najis & Sholeh Hasan, M.Pd.I \\
\hline 16 & 18 Apr. 2018 & $18.45-20.15$ & Haid, Nifas, Istihadoh & Sholeh Hasan, M.Pd.I \\
\hline 17 & 25 Apr. 2018 & $18.45-20.15$ & Haram sebab Haid dan Nifas & Sholeh Hasan, M.Pd.I \\
\hline 18 & 02 Mei 2018 & $18.45-20.15$ & Haram sebab Junub & Sholeh Hasan, M.Pd.I \\
\hline 19 & 09 Mei 2018 & $18.45-20.15$ & Haram sebab Hadas Kecil & Sholeh Hasan, M.Pd.I \\
\hline 20 & 16 Mei 2018 & $18.45-20.15$ & Bab Shalat & Sholeh Hasan, M.Pd.I \\
\hline 21 & 23 Mei 2018 & $18.45-20.15$ & Shalat Lima Waktu & Sholeh Hasan, M.Pd.I \\
\hline 22 & 30 Mei 2018 & $18.45-20.15$ & Syarat Wajib dan Shalat Sunnah & Sholeh Hasan, M.Pd.I \\
\hline
\end{tabular}

Untuk membentuk aspek-aspek dalam diri manusia dibutuhkan pendidikan yang terencana dan berkelanjutan. Aspek tersebut meliputi: aspek keilmuan, aspek keterampilan, aspek kesenian dan aspek keagamaan. Dalam rangka pengembangan aspek itulah maka dibutuhkan lembaga-lembaga yang mampu menyalurkan dan mengarahkan pendidikan yang sesuai dengan kebutuhan manusia tersebut.

Proses pengembangan pembelajaran kitab kuning yang terlaksana, tidak dapat dilepaskan dari kendala-kendala yang akan terus berkembang seiring bertambahnya waktu, lokasi, serta jumlah santri. Oleh karena itulah solusi-solusi yang kreatif yang mampu menyelesaikan kendala-kendala yang akan dihadapi nanti harus tetap terus dikembangkan.

Pendidikan senantiasa mengandung pemikiran dan kajian, baik secara konseptual maupun operasionalnya, tak terkecuali kajian-kajian kitab klasik. Sehingga diperoleh relevansi dan kemampuan menjawab tantangan serta memecahkan masalah-masalah yang dihadapi oleh umat manusia.

Proses pengembangan pembelajaran kitab kuning yang terjadi juga dikarenakan keaktifan para ustadz, pengasuh pesantren, pengurus pesantren serta santri dan santriwati. Sebab itulah keaktifan ini perlu dibina dan diteruskan, sehingga dapat menjadi budaya yang mengakar kuat dalam masing-masing pribadi tersebut.

\section{SIMPULAN}

Kesimpulan yang didapat dari kegiatan pengabdian ini adalah: menanamkan nilai-nilai yang terkandung dalam kitab Fath al-Qorib pada dasarnya dapat dilakukan melalui jalur pendidikan apapun. Namun yang hingga saat ini masih konsisten adalah jalur pendidikan nonformal; untuk membentuk pribadi-pribadi muslim yang berkarakter islami dan mampu menjawab tantangan jaman khususnya masalah-masalah fikih maka sudah selayaknya orang Islam mengkaji berbagai literatur klasik yang satu di antaranya adalah kitab fathul qorib.; Kegiatan pengabdian ini mungkin sangat sederhana, namun jika dijalankan secara berkelanjutan akan dapat digunakan untuk menghasilkan generasi-generasi yang handal dalam melestarikan kajian islam melalui kitab-kitab klasik.

\section{UCAPAN TERIMAKASIH}

Ucapan terimakasih penulis sampaikan kepada beberapa pihak yang turut serta membantu mensukseskan kegiatan pengabdian ini, antara lain:

1. Sekolah Tinggi Keguruan dan IImu Pendidikan (STKIP) Nurul Huda OKU Timur yang sudah memberikan dukungan penuh terhadap tugas dosen terkait tri darma perguruan tinggi.

2. Lembaga Penelitian dan Pengabdian Masyarakat (LPPM) di bawah naungan STKIP Nurul Huda yang 
telah memberikan support, bimbingan dan arahan dalam melaksanakan program pengabdian kepada masyarakat melaui surat edaran nomor 006/STKIP-NH/LPPM/II/2018 tahun 2018 tentang penandatanganan kontrak hibah STKIP Nurul Huda tahun 2018 periode \#1.

3. Lembaga Pondok Pesantren Darul Ihya yang telah memfasilitasi penulis dalam melakukan kegiatan program pengabdian kepada masyarakat, dan

4. Seluruh pihak terkait baik secara personal maupun kelembagaan yang turut serta memberikan kontribusi.

\section{DAFTAR PUSTAKA}

Azra, A. (2001). Pendidikan islam tradisi dan modernisasi menuju meliniu. Cet. ke-3, Jakarta : Kalimah.

DEPAG RI. (2003). Pondok Pesantren dan Madrasah Diniyah, Pertumbuhan dan Perkembangannya. Jakarta : Dirjen Kelembagaan Islam Indonesia.

Depdiknas. (2008). Kamus Besar Bahasa Indonesia. Jakarta: Balai Pustaka, Edisi 5.

Fajar, M. (1998). Visi Pembaruan Pendidikan Islam. Jakarta: Lembaga Pengembangan Pendidikan dan Penyusunan Naskah Indonesia /LP3NI.

Qosim, I.A. Fath al-Qorib al-Mujib. Surabaya: Maktabah 